\title{
COVID-19 Lockdown and the Needs of Catholic Christians-Perspective from one Diocese
}

\author{
Ujunwa Patrick Okeahialam, $\mathrm{PhD}$ \\ Sacred Heart Church, $7154^{\text {th }}$ Street Alamosa, CO. 81101
}

\begin{abstract}
The ravaging fears, force of infection, and death arising from COVID-19 pandemic led to the lockdown of virtually every aspect of society. In readiness for the possible unknown arising from the lockdown policy, many people resorted to stocking-up on the things they considered essential such as, food, toiletries, and medications. These things are material and quantifiable things. Although the church is a community of people, it is also, considered a spiritual society. Since the church was not treated as an essential institution to be left open at the height of the lockdown, and considering its spiritual connection, this study aimed at finding out what the people stocked-up on as essential in order to be sustained in their faith. The result from 39 returned survey-questionnaires conducted in the diocese of Pueblo, Colorado USA showed that people only substituted, on their own, for what they considered essential (i.e. the sacraments). This, holds policy implications for the Catholic Church leadership to articulate, now and for the future, such as the need for church libraries, adequate technological adaptation, in-depth catechesis, and solemn celebration of the liturgies in order to help adherents cope better in times of uncertainty.
\end{abstract}

Keywords: Lockdown, Stock-up, Essential, Eucharist, Catechesis, Spiritual Resources, COVID-19

DOI: $10.7176 / \mathrm{PPAR} / 10-11-09$

Publication date: November $30^{\text {th }} 2020$

\section{Introduction}

With the announcement of the lockdown protocols in different places due to the COVID-19 pandemic, people panicked and exhibited different forms of behaviors. One such behavior was the stocking-up on things considered essentials. Some of them include water, toilet papers, and hand sanitizers. There were also stocking-up on staple food items and medications for many who are sick. Although majority did this because they do not know how long they will be locked-down, there were others who did so, in order to create scarcity with the intention to resale the items they horded later; like the two Tennessee brothers whose activities were cracked by Amazon (Nicas, 2020). Generally, the stocking-up on essentials was for many, the need to have enough to last them until the lifting of the lockdown regulations.

Although many public officers encouraged houses of worship to suspend in-person gatherings as ways of helping to flatten the curve and reduce spread (Inazu, 2020; Siddiqi, 2020), there remained the divide among many, whether or not to classify the church as an essential institution that should remain open or a non-essential one that should be closed (Jelten, 2020). The discrepancies in the application of this divide led to the Department of Justice's joining in the case in Mississippi where it argued that religious institutions should not be singled out for special burden that similar places of gathering are exempt (Johnson, 2020). This tension is not unique to the handling of COVID-19 pandemic. During the Spanish Flu pandemic, churches and many public places were also closed, not to everyone's delight; as some people ignored the directive arguing that the situation called for more church and prayers (Bjoershol, 2013; Haack, 2019; Stetler, 2017).

The Catholic Church as an institution did not allow herself to be dragged into this debate, even though she considers herself as essential. She rather leaned more on the need for public health (Zimmermann, 2020). Consequently, the church advised for a lockdown of the churches, while counselling priests to maintain private celebrations on behalf of the people. They also advised following the guidelines from civil authorities as regards to the number of people allowed in a particular ritual space. Added to these were regular updates and guidelines for ministries in the limited ministerial climate of the pandemic from the Vatican, National Conferences, as well as dioceses.

Although some Christians felt that the hierarchy of the church cowered under governmental pressure by locking down churches, they still obeyed to remain at home. This study therefore, sought to find out what parishioners considered essentials for their continued spiritual life and nourishment in the lockdown situations. The study is not aimed at finding the willingness or the reluctance in the people with accepting the conditioned lockdown. To arrive at this, the study inquired into the things people tried to gather to last them during the lockdown, since they know that they will not be physically going to church. Knowing this, and what they missed most about the church during the lockdown, this study proposes to help in the development of standard policies of operation for the parishes on how to sustain the faith of the members during and outside challenging times as this.

\section{Problem of Study}

Every diocese is considered, a segment of the church in a local place and it is called a "particular church" 
(Catechism of the Catholic Church, \# 833). This uniqueness does not translate to uncontrolled independence. As a result, there exists legal frameworks for a uniformity of practice and outlook of which the Canon Law and Catechism of the Catholic Church are examples. What the diocese represents in the universal church is similar to what the parishes are in the local dioceses. As particular churches, different dioceses do issue guidelines about the pastoral life, which are supposed to be implemented by the pastors. These could arise from perceived problem or just a project to give direction in the life of the church as in acts of diocesan synods (Shimek, 2014).

However, it does not always happen for one issue to grip the hierarchy and members of the universal church at the same time while freezing direct access to the ordinary life of the church, in word and sacrament. With the COVID 19 pandemic, churches were closed, the clergy and parish staff were encouraged to be safe, and the people were quarantined - yet the church must be felt to be alive. Consequently, both the leadership of the church and the people made efforts to keep up with the celebration of the faith. Without the pleasure of knowing what the people considered essential, that ought to be provided adequately, different parishes and pastors supplied the best they could with the hope that it will sustain the faith of the people while the lockdown lasted. However, it remains a big question if the things done satisfied the peoples need.

\section{Purpose of Study}

The purpose of this study therefore, is to find out what people considered "essential" in their living of the faith. The identification of this (these) is intended to help in the pastoral policy formulation about what should be supplied adequately for the church communities and ways it (they) can be made available should incidents like the present pandemic happen again.

\section{Research Question}

The study intends to answer two basic questions: 1). What formed the believers' rock-foundation in the absence of the ordinary ritual patterns and structures? 2. How did they nurture their faith and spiritual life during the lockdown? The following sub-questions were asked to be able to answer the two basic questions 1). At the news of the lockdown, what spiritual material(s) did you try to get more of to last you during the lockdown? 2).How did you connect with your faith community during the lockdown? 3). How did you sustain your faith and spiritual life during the lockdown? 4). What aspect of church life did you miss most during the lockdown? 5). what lessons have you learnt about faith and spirituality during the lockdown? Lastly, respondents were given the opportunity to add any comment they have.

\section{Theoretical Framework \\ Hierarchy of Needs}

Since this study aimed at answering the question of what the people tried to gather to last them in the lockdown situation, the thinking is that they will go for what they considered most fundamental or essential for their spiritual survival. This thinking necessitated the choice of "Hierarchy of Needs" as the theoretical framework for the study. Hierarchy of needs as a concept was popularized by Abraham Maslow in the paper "A theory of human motivation" (1943). The core of this theory is that humans are driven to self-actualization. In this quest, "Satisfaction" is the topmost block of the structure. However, this structure is built with one need on top of another beginning with the fulfilment of a prior need. The foundation of these needs are the physiological ones. It is on top of this that the others are built such as the safety needs, the need for social belonging, and lastly that of self-esteem (Selfactualization). The sense of this theory is that the core of human needs is the physiological and without satisfying it, the inclination to pursue the other needs will be negligible. At this physiological core are such needs as food, shelter, clothing, etc. These by implication will be the things people, at core, will struggle to satisfy or stock-up on in the face of uncertainty.

Trying to identify an organizational core from this perspective may not be easy because it goes beyond what are referred to as organizational objectives. Organizations and institutions, although work towards their objectives one-step at a time, but the level of appreciation from those they serve are different. For instance, the church exists to extend the ministry of Christ (Acts of the Apostles, 1:8), yet peoples attraction to the church are influenced by different things. Those attractions show the different needs, making it impossible to define an intellectually pure hierarchy of needs of church people. Therefore, the stocking-up mentality evoked by the pandemic offered an opening to find if there is unanimity in the core of what believers need drawing from what they tried to stuck-up.

Unfortunately, when people hear about hierarchy in the church, it is not always about needs but about governance and power. This is the tendency to say that the church is hierarchical — while looking at the leadership structure in the church, which the clergy holds. At this, the lay community forms the base. However, it is a base from which the other governing building-blocks are formed. Consequently, the post-conciliar document of the Second Vatican council began its presentation of the people of God (the church) with the baptized as the core of membership. It is from the body of the baptized that the body of functionaries emerge. Therefore, the hierarchy of membership in the church starts with baptism as the most essential-something, hopefully, people should have in 
the face of uncertainty as well.

Apart from this, one can deduce from the sacramental life of the church another hierarchy. On this hierarchy, Holy Eucharist is held as core and central, among the seven approved sacraments with the sense of containing Christ's real presence (Osborne, 2007), and as memorial of Christ's saving activity (Worgul, 1980). Drawing from this, the Second Vatican Council's document on sacred liturgy (Sacrosanctum Concilium, 10, 4) referred to it as, the source and summit of the life and practices of the church (Flannery, 1981). Another insight of the place of the Eucharist is the insight credited to Henri de Lubac that "The Eucharist makes the church and the church makes the Eucharist." (Le, 2006). It is also said that, no parish is complete without the Eucharist. It is in this context that one understands Pope Benedict's words that, "Without the Eucharist the church simply does not exist. (Kerr, 2011). The same sentiment flowed in the words of the 4th century Abitinae martyrs, said to be popular with Pope Benedict XVI (Imbelli, 2007) that, "sine dominico non possumus" (which is literally translated as, "without the Sunday Eucharist we cannot live"). From these, it is so clear that the church values the Eucharist as core. This core is not without qualification. It defines the local community as well as the body of believers who gather as an assembly drawing "life from the word of and the body of Christ and so herself becomes Christ's Body" (Catechism of the Catholic Church, \# 752).

From this, it follows that what the people would have wished to stock-up more than anything is the Eucharist, since it is presented as the core. However, the Eucharist is not so material a thing that can be stoked-up by the believers. In addition, the making of the Eucharist in the church is community oriented-something made more difficult by the lockdown and the injunction against public celebration of the liturgy. Therefore, held back from accessing the most essential item of Catholic spirituality and life, it becomes even more imperative to know other things the people stocked-up on in order to sustain themselves spiritually.

\section{Method: Data Collection and Analysis}

The method of study is qualitative using open-ended questionnaires. It used the diocese of Pueblo as a microcosm of the experience of Catholics during the pandemic. The questionnaire was sent to the chancery for dissemination in the diocese through the pastors. Although the study focused on the actions of lay Catholics, a non-Catholic and a Catholic priest were allowed to respond to the same questionnaires to serve as control. Respondents were given options to insert their phone numbers should there be need for follow up questions-which some did. They were assured of their confidentiality in the study and that the return of survey is an indication of acceptance to be part of this study.

The study period began mid-June and lasted to the end of August and the study is not sponsored by any organization nor was compensation offered to respondents in any form. There was direct efforts made to at least a priest from each of the deaneries of the diocese, through emails and phone calls in order to facilitate some balance of spread. About 37 respondents (Apart from the two control ones) returned their questionnaire, apart from two control-responses. This appears like a small sample size, however it showed spread and representation from the deaneries that the study wanted to capture. The initial analysis was to determine the deanery distribution-which revealed the following: Alamosa deanery (12), Pueblo deanery (4), La Junta deanery (12), Durango deanery (6), and Grand-Junction deanery (3).

\section{Spread of Respondents}

Three measures were built into the survey: gender, age, and educational attainment. The idea was to find out how the designations influenced the responses. However, of the 37 returned questionnaires, the number of female respondents was significantly higher than the male $(70 \% \mathrm{v} .30 \%)$. This supports the prevalent perception of the presence of more women in the church than men regardless of the reason why (Gee, 1991; Lazerwitz, 1961; Podles, 1999). Equally significant is the higher number of respondents from the age 66 years and above. It also supports the observations of a more elderly demographic of regular church attendees (Gonzalez, 2020; Krause, \& Wulff, 2005). On the other hand, there seem to be a better mix of educational attainment between the various end levels. Below is a tabular presentation of the breakdown in percentages. 
Table 1

Distribution of Respondents

\begin{tabular}{llll}
\hline Areas of Measure & Gender & Age & Education Attainment \\
\hline Male & 30 & $\mathrm{X}$ & $\mathrm{X}$ \\
Female & 70 & $\mathrm{X}$ & $\mathrm{X}$ \\
15-20 years & $\mathrm{X}$ & 3 & $\mathrm{X}$ \\
21-30 years & $\mathrm{X}$ & $\mathrm{X}$ & $\mathrm{X}$ \\
31-50 years & $\mathrm{X}$ & 5 & $\mathrm{X}$ \\
51-65 years & $\mathrm{X}$ & 27 & $\mathrm{X}$ \\
66 years \& Above & $\mathrm{X}$ & 65 & $\mathrm{X}$ \\
High School & $\mathrm{X}$ & $\mathrm{X}$ & 27 \\
College & $\mathrm{X}$ & $\mathrm{X}$ & 38 \\
Graduate & $\mathrm{X}$ & $\mathrm{X}$ & 35 \\
\hline Total & 100 & 100 & 100
\end{tabular}

With the above mix in educational attainment, it follows that the results have nothing to do with uninformed piety. Consequently, it will be helpful to apply them in the policy formulations of the church, to be able to guide her members in tumultuous times, as the present COVID-19 pandemic.

\section{Limitations}

Due to lockdown in place, it was not easy to get as many respondents that was intended, neither was it easy to do more to ensure proportionality in spread. The same limitation hampered the return and collation of responses. However, the study went ahead because the uniqueness of the situation. Also not knowing how much longer the pandemic restrictions will last meant that no time should be wasted in identifying what people consider essential for them to keep connected with God and the church as the condition endures. Another reason why this study is important is that since the church continues to serve and minister during this pandemic, it will be proper to know how best to channel her resources in order to account for her members when the restrictions are eventually lifted. Although some ways of responding to this need is ongoing, the immediacy of the pandemic meant that none of them started after adequate survey of what the people considered as their utmost needs - and the need for informed policy direction cannot be overemphasized.

The limitation about the distribution of survey was mitigated by direct mails to some priests in the diocese. This was primarily done in order to ensure proper deanery spread of the study.

\section{Result}

Question 1: At the news of the lockdown, what spiritual material(s) did you try to get more of to last you during the lockdown?

The direction of this question is multifaceted but intended to understand the ideological bent of respondents about the church as materialistic or spiritual, although the questions premise looked materialistic. The social perception of peoples attitude towards the lockdown showed them buying several things considered essential. These they wanted enough of to last them for a long time because they may not go to the stores soon. Many Christians, as well as the respondents, considered the sacraments and the ability of members to congregate as essentials that cannot be stocked-up. Therefore, their responses were more about how they knew to keep spiritually nourished in the absence of congregating for services and liturgical celebrations. Many respondents identified stocking-up on different written spiritual resources. There were others, also who resorted to different online spiritual resources especially through the United States Conference of Catholic Bishops (USCCB) links.

With the overwhelming response about written/literary materials, a follow up question was asked, if those were accessed through parish library or bookstore. None indicated getting from parish library and some were oblivious if their parishes had libraries. Some responded to knowing of spiritual stores within and around their parishes but felt that they could not access them in the lockdown. They therefore, depended on what they could purchase elsewhere or online.

Curiously, one respondent's answer was, "None." Upon further inquiry, the respondent spoke spiritually about her resignation that the essence of the church is spiritual and cannot be purchased or horded. Therefore, what she did was to cultivate a more conscious awareness of the presence of God and to create purposeful moments to pray and meditate. One person spoke of buying a Monstrance (An open or transparent receptacle in which the consecrated Host is exposed for veneration in the Catholic Church) and asking the pastor to come and consecrate the Blessed Sacrament for her to expose in her house. Asked if that was done, the respondent indicated how she felt pained when the pastor told her how difficult that would be, unless she got a special permission from the Bishop.

Question 2: How did you connect with your faith community during the lockdown?

The essence of this question draws from the ecclesial nature of the church as an assembly (ecclesia) of the people 
of God (Catechism of the Catholic Church, \# 751; Osborne, 2007). In the church, the height of its celebrations and life is liturgical, which according to decree on sacred liturgy of the second Vatican council, is a form of public prayer (Sacrosanctum Concilium 9, 7). Respondents to this question acknowledged how difficult it was cutting off from their usual contacts with their parishes. This was because for some, the ability to come around to the church when they wish for Holy Mass and other activities was one of their life's outlets. Many of the respondents within the ages of 66 and above identified church friends as a part of their closest friends and so expressed the strain of that cut-off.

However, all the respondents did keep some measures of contact with their faith community. They indicated keeping contacts with friends mainly by phone; but with the church as an institution, this statement from one of the respondents summarizes what it was for many. It said, "We were able to keep in touch with many in our faith community. We shared upcoming programs, beautiful prayers on messenger, texting, and calling each other often." There were also responses about calls from pastors and various church functionaries and committee heads to check on members. For most respondents, keeping in touch with the faith community was demonstrated in the ability to participate at livestream masses. Some respondents also indicated the flexibility they had to log into other parishes' programs via online resources. Among these groups, some felt a greater connection to programs and better streaming from other parishes than their own.

Question 3: How did you sustain your faith and spiritual life during the lockdown?

Recognizing the place of the church and sacramental celebrations in sustaining the faith of believers, this question sought to find out how people filled the need in the absence of open celebration in the church. All the answers pointed to joining different livestreamed services from different churches, daily prayers, reaching out to friends in the church to discuss issues of faith and praying together, visiting the Blessed Sacrament, and finding time for mediation.

Reflecting the sense of meditation one of the respondents wrote, "Thanking our Lord for blessing us with his divine presence in our lives." These are apart from, the many spiritual literatures and several online resources that they utilized. Some indicated with appreciation how they were able to access the FORMED (An online integrated catholic resource for bible studies, catechetical formation, etc. It can be accessed at www.formed.org ) resources through their parish account. Particularly, one respondent said, "The FORMRD resources was handy and very enriching."

Question 4: What aspect of church life did you miss most during the lockdown?

Responses to this question centered on the initial absence of a general and a later limited participation in the celebration of the Eucharist. Some of the words used in expressing this include, "The Eucharist", The Mass", "Receiving the body and blood of our Lord." Writing more profusely one respondent stated, "I missed daily mass and communion. It has always been a lifeline for many of us regulars. I find solace going to church or chapel early. It is the best way to start the day."

Question 5: What lessons have you learnt about faith and spirituality during the lockdown?

From his question, one got a variety of answers. Some examples include, "faith is tested and rootedness is essential," "faith and hope, for this too shall pass," "we as people of God need to talk to God more and trust in him, give everything to him and put all things in his hands," "l learned that there is war on religion," "the importance of holding on." One respondent expressed the sense of loss and helplessness at the onset of the lockdown. However, the respondent later realized an inner strength she never knew she had and the calming power of private prayer. Asked further about the war on religion some respondent wondered why the church is not designated as an essential institution while the liquor stores were. Speaking further, one respondent queried, "if it was better to bury people's frustrations of the moment in drugs and alcohol or to go to a place where one can seek the face of God and to find meaning."

In all, the respondents indicated that the pandemic has shown the emptiness of a life that is not anchored on faith and hope. From these it was clear that the people's rock foundation was the awareness of the place of God in human life. However, this awareness is not abstractly nurtured but in ritual events; and it was to satisfy the latter that led people into the things they tried to stock-up on. Speaking about how everyone, rich and poor, black and white are scared of dying and are held-up at home, one respondent said, "I am sure that most people after this, will come to appreciate the importance of God in human life, and of building a good family. This is because at times like this, we have no place else to go than our trust in God and to be with our families."

\section{Discussion}

The COVID-19 pandemic has been very catastrophic in its effects. From the World Health Organization Coronavirus disease dashboard of October 15, 2020, there were 38,394,169 confirmed cases and 1,089,047 deaths from COVID-19. Also World Bank (June 8, 2020) feature story, forecasts a 5.2\% contraction in world GDP as a result of the pandemic. Equally, the pandemic has exposed some inequalities in the society especially that of race (Lee, 2020). It has also shaken diplomatic relations between nations with the US accusing China of the origins of the virus (Sanger, 2020) and the Chinese pointing accusing fingers at the US army for the same (Winter, 2020). 
And thinking that the WHO was working in cahoots with China's misinformation, President Trump on July 7 , 2020 pulled the US out of the WHO (Hinshaw, 2020). It was also in the newsable.asianews.com of May 19, 2020 that the President of Madagascar urged African States to quit WHO for the body's bad faith in endorsing its herbal therapeutics.

Equally, its effects have become sore points in the debate between the haves and have-nots with regards especially, to access to health care and people's wellbeing. These effects did not spare the church, as many of her activities were re-thought. How long the rethinking will last is unknown since the pandemic is still ravaging nations and peoples. What is known and feared, however, is that it may not be the same again in all aspects of church life.

Considering these, it would have been simpler to wait to the end of the pandemic before this type of study. However, the short-term plans many people put in place have continued to be amended-hence the need for policies to be articulated with the intention of a far-reaching result. This is because the church does not weld the kind of power it had in the past over many populations. For instance in the response to the Spanish flu there were elements in the Portuguese as well as in the South African church that claimed the flu as an act of divine punishment for crimes against religion and other social dissonance-including people not going to church and their placing science above every other thing. The weapon to assuage this they claimed include prayer, penance, and other acts of atonement (Lima \& Sobral, 2020; Phillips, 2008). Due to the prominence of the church in society then, they could get many to perform prayer processions. Also in the past with less secular social service outfits, the church could offer her facilities and permit her array of priests and religious to help as chaplains and nurses (Stetler, 2017; Thomson, \& Bolten, 2018).

In today's society, there are enough of these resources available outside the church. In addition, different nations and groups today extended generous packages of palliatives to her citizens - such that recourse to the church is minimal. Equally, some in response to humanism volunteered to help with no sense of religion attached. Given these scenarios, this study, from the results of the survey, proposes the following as possible directives that churches can follow to sustain the faith of their members during this pandemic and other similar conditions of cutoff from direct church life.

\section{Improve on Modern Technology and Library Development}

In compliance with national/state directives, the church closed her doors to public services within her facilities. This was not tantamount to closing church life because liturgical services continued partially; and with time limited attendance by the people was authorized. Since church ministries are always undertaken for the good of the people (liturgy), there emerged ways of transmitting these services. It was reported for example, that during the Spanish flu lockdown churches within the Cleveland area had homilies written and sent to the people (Bjoershol, 2013). Some pastors also used the newspapers to disseminate information about the hymns people could sing, the prayers, and scriptural passages they could read as they met in their homes during the service hours. Also during the same time, the use of telephone in the work of evangelization peaked, that even Bell telephone in Canada encouraged for less use due to network flooding (Reilly, 2020). In the present instance, several livestream services are undertaken using different social media outlets.

Similarly, respondents showed that the church within the diocese of Pueblo did things to transmit their services by Facebook, YouTube, Zoom, etc. However, some respondents commented about the many people who felt disconnected because they do not use Facebook and do not have cable TVs to be able to connect, in the alternative, to the diocesan broadcast or the EWTN. Some too, do not have smart TVs as to connect to the YouTube for better delivery. Some commented of the inability to be glued to their cellphones for church services because they could be straining their eyes and ears. This was compounded by a near amateur livestreaming apparatuses form the churches who were not prepared for the enormous challenge they faced with the pandemic.

The tendency will ordinarily be the call for upgrading and updating of equipment. However, it will be out of place for every church to set up mini broadcasting networks. Apart from the high cost of setup, it will also amount to spikes in the budget of the different parishes if specialists are to be hired to run the outfits. Moreover, any idea to set up one big studio in every diocese as more cost effective will further alienate people from their local parishes.

Considering the question of what people sought to get more of with the news of the lockdown, we imagine what can be done more easily to nourish the people's faith now and in the future. Since more people found their nourishment from spiritual literatures, it will be important to articulate a system of having and improving the library holdings of parishes to attend to this need in a way that connects people to their parish communities. The pertinence of this is that in a definite case, one can imagine the number of books to buy but as the life of the pandemic is unknown and with the fear of upcoming waves of it (Achenbach \& Weiner, 2020), not many people can afford the luxury of restocking-up indefinitely. It becomes imperative that parishes can help by setting up and arranging better library spaces.

Asked if their parishes have libraries, an overwhelming number of respondents could not tell. The implication is that parishes have not paid attention to this way of nourishing their parishioners. Although different parishes, given their connections with parochial schools have some books, and semblance of library holdings, these are unfortunately stowed away but they can be more easily started with minimal cost. 


\section{Need for Improved Catechesis on Prayers}

Another insight from this study can be framed as the need for improved catechesis on prayer. Although majority of respondents indicated that they loaded on literatures and other related resources, there were a few who did not. However, further inquiry on how they coped revealed a deeper need that calls for greater attention. For instance, one person's response as to not loading on literatures to fill the gap was, "it's all about the ability to be aware of the ever presence of God and to be connected with him. I know that he is with us even in the pandemic and that I share in the ministry the priests are performing privately." This is a commendable depth of faith in the mystery of the Church and the essence of the church's practices. However, since it is an outlier response, it demands that the church should be more attentive to the issue of catechesis.

The wealth of the experience of Teilhard de Chardin (1965) remains an opener to how one can continue to be in the mood of celebrating the mysteries of the church in the absence of sacramental matters. Throughout the history of the church, her members have endured persecutions from place to place and from time to time. During these instances their gathering as a body are almost impossible. Therefore, the survival and growth of the faith have always remained in the convictions of the people in the imperative of faith-principle for their lives-and this is only possible with grounded catechesis. There are also instances where people of faith migrate into new territories where they do not have the immediate services of their ordained ministers. The case of the ethnic churches in the catholic history of the United States is one example. Before the arrival of the ordained minsters to these communities, it was known that these people held on to the faith because it was deeply rooted in them already (Connor, 2017).

Moreover, the Christian faith from the time of the apostles had spread because believers took their faith as they moved along the way (Okeahialam, 2015). This is equally supported by one of the respondents who said, "Faith is tested and rootedness is essential." It is the rootedness, which impels one to live the faith no matter the circumstance and to be able to share it as well.

Unfortunately, some of the respondents felt, not only the temporary shock and sense of loss when access to the church and the celebrations of the church were shut down, but expressed not knowing how to cope spiritually in the circumstance. An approach here will demand that priests will reappraise their positions as the chief catechists of their parish communities. This position falls to them as representatives of the Bishop, who is the chief catechist of the local church-and who ensures that effective catechesis is operational in the diocese (National Directory for Catechesis, \# 54). Priests will have to maximize the opportunity provided by the pulpit to give faith-filled homilies that are also rich in doctrines and not just offering platitudes to the congregants. Equally, they should reevaluate the contents of the catechetical models used in their parishes to be sure that they have true balance of both human and doctrinal formation. And since they cannot handle the whole catechesis of the parish alone, they should be more involved in the recruitment of those who will do so and equipping them with what they need to succeed. Most importantly, every diocese should institute functional department of catechesis (as recommended by the national directory for catechesis) that can effectively coordinate this in the entire diocese; while every pastor should be directly involved in the planning and execution of the parish catechetical protocols in compliance with diocesan directives.

\section{Need for a Living Liturgy and Community}

This need arose from what respondents answered as the thing they missed most during the lockdown. Prominently emerging from the contribution of respondents about what they missed are the Eucharist and the community. Concerning the Eucharist, respondents expressed how different it was for them missing in-person attendance at Mass and getting the opportunity to receive Holy Communion. Some even indicated that they did not feel it to be the same when they had to be in another room watching the mass or participating in a drive-in mass. Noticing this as something missed, some respondents were asked of their hope when the doors of the church are fully opened. The response to this latter question include a solemnly celebrated liturgy where priests give it their best and their all without acting to be in hurry and unprepared. One respondent said, "I don't like the priests to make liturgies look like a drama they got to get through with. I like it solemn." This attachment to the sacraments is not unique to this sampled population. A similar survey by Gonzales (2020) showed that $69 \%$ of the US Catholic magazine survey participants, identified that the best part of being catholic is the sacraments, chief of which is the Eucharist.

The sense of building a conscientious Christian community came from respondents who think of the high level of individualism in the contemporary society. For most of these, the best friends they have are their church friends. Asked why consider church friend as best friends one of the respondents said something like the fact that their associations are not sustained by material things nor professional bonding's, but by the quest for God and heaven-making them more sincere and trustworthy. It was expressed that those fellowships in the church and with church friends need to continue because they are the only outlets that some have where they can be safe and relax freely without being judged. Although this will be uphill tasks for churches to put together because of different health and safety concerns, yet it is important to know that the people seek this space and attention from the church. The church is always an ecclesia that began in the quest for a kingdom. It means that the church should promote the best ways people can feel the sense of community as a foretaste of the kingdom of love, justice and 


\section{peace.}

\section{A New Church}

The idea of a new church is put together drawing from the various inputs that respondents entered under general comments. It is good to note that not all the respondents shared something in this section and many of those who shared something indicated their reminiscence of their churches and pastors. However, there are entries that call for some attention. Two responses summarize those reminiscing comments. The first one states, "I long for the way we were in 2019"; and the second is, "I want life to return to normal soon." For many others, the lockdown was an awakening call to cultivate, more seriously, an awareness of the ubiquitous presence of God; and how to nurture a relationship with him, especially through prayer. For some also, the loneliness of the moment shows how much people need each other and to have a strong faith to cope with the challenges of life. Someone indicated that the pandemic became a zero-sum game that scared everyone and put most of life to a halt not minding our various socio-economic statuses.

In response to this predicament, some indicated creating spaces in their homes for purposeful encounters with God through prayer and joining in livestreams services from their parishes and other religious cable channels. There were also some comments of appreciation to pastors who continued to be there for their parishioners and who evolved ways of celebrating the sacraments for the students in religious education. However, some were critical of the church hierarchy for submitting to the closure of the churches whereas some other public places were allowed to operate. One respondent wrote this, "I think the Bishops made a grave mistake by allowing churches to be closed by the government. The first amendment to the constitution states, no law prohibiting the free exercise thereof. If there is a class action lawsuit, I am in."

How far people who share this sentiment will go and continue to be loyal is unknown or asked for in this study. However, it reveals the presence of some embers of disaffection for the churches leadership - even though the church acted for the good health of their adherents. Apart from this, there is the fear that some people will get used to sitting at home to watch livestreamed celebration of the Mass and other sacraments. With present day level of technological innovation where people can see, hear, and even comment their likes and disaffections in realtime this fear is more. With this, some people will think that they are not missing a thing by continuing to participate online. And with the fluidity people are enjoying with the ability to choose the parish or the priest that is offering what the want, the issues raised by Harvey Cox (1965) about how mobility shapes modernity is rekindled.

Another issue of interest will be if the teaching of the church about keeping the Lord's Day holy by attending and participating at Mass (Sacrosanctum Concilium 9, 25) go through some revision because of how the issues of the moment are handled. This is unknown and a reference to the past may not be enough to satisfy a contemporary mind given how many relationships and transactions are accomplished remotely. However, the church will have to prepare to respond to the challenge going forward. In the meantime, surveys show dwindling attendance by people who identify themselves as Catholics. And with the increase in the number of those who identify as "Nones" (Olson, \& Beckworth, 2011) in areas of religious affiliation, other religious communities are equally feeling the drop. Will that scenario and the effects of the resent pandemic responses lead more people to demand online attendance as fulfilling of Sunday obligation is something to watch out; and it will be important for theologians and members of the Discatary on worship to begin working out some answers. This suspicion was captured by one of the respondents who wrote, "We were surprised when the church opened again that so many people did not return even though the church is cleaned."

\section{Conclusion}

The present restrictions undertaken as response to the COVID-19 pandemic are not only being felt in the larger society, they have also impacted the church as well. Although the church was guided by health concerns to save lives, no study of what the people really needed in order to cope with their faith-nourishment under the lockdown had been undertaken. This makes this study timely since the pandemic endures and experts speak of possible spikes in the future. Moreover, similar conditions can arise in the future that will demand a research-based solution in order to be addressed adequately.

Articulated from what the people stocked-up on and what they missed most, this study saw the need for parishes to update on the use of modern technology and to pay more attention to the need for library spaces and holdings. The latter need was unique to the lay community because the response from the priest, used as control, was in another direction. He responded that, "We stocked the sacristy with Mass wine, Altar hosts, and candles. We also stored up toiletries and disinfectants." This response was more inclined to administrative concerns and similar to the response of many other priests contacted in the way of peer review throughout the course of this study. It revealed an assumption that the people will be there and will be coming - a situation that did not happen with the limited opening. This assumption also is at the heart of why many parishes do not focus on evangelism, even in the face of dwindling congregants.

Looking at the submission of the non-Catholic, used also as control, the response to what was stocked-up on 
was, "Bible and Prayer Book;" and what was missed for that respondent include songs/hymns, preaching, night vigils, and bible study." Conspicuously missing here is the Eucharist and this goes to support the Bible-centered place in Protestantism compared to the mass of liturgical functions in Catholic spirituality and practice. Consequently, catholic clergy should see the need for a conscientious celebration of the liturgies with solemnity, realizing that they are chief characteristics of Catholicism and the greatest thing that their members missed when they are not openly offered.

The thought about a new church is not used to condemn what is now. It is rather used to awaken the leadership of the church about the need to prepare for the fall-out from present lockdown experience. It acknowledges how some people will want the online membership to be permanent against the sense of ecclesia (assembly) which many feel are needed to overcome the negativities of contemporary individualisms. Another sense of a new church is the observed responses of the disappointment of some believers that the church hierarchy could not stand to argue that the church is an essential institution. Recognizing how one respondent stated the readiness to join any class action lawsuit to that effect, this study fears the possibility of some people ready to follow any emergent radical leadership that speaks to the people's sentimentality.

This study, overall, is one way of looking at the effect of the COVID-19 on the Catholic Church, and so is not exhaustive. Further research will be needed to address more specificities such as the impact of the lockdown on the different demographic membership of the church. It will also be important to know if the Church as an institution, had guidelines of living and celebrating the faith in circumstances as this and if they were faithfully applied.

\section{References}

Achenbach, J. and Weiner, R. (September 5, 2020). "Experts project autumn surge in coronavirus cases, with a peak after Election Day." The Washington Post. www.washingtonpost.com

Baker P (May 22, 2020). "Firing a salvo in culture wars, Trump pushes for churches to reopen." New York Times. www.nytimes.com

Bjoershol, H. (2013). "Fighting the Germans. Fighting the germs: Cleveland's response to the 1918-1919 Spanish flu epidemic." ETD Archive. 850. https://engagedscholarship.csuohio.edu/etdarchive/850

Catechism of the Catholic Church (1997). Vaticana: Librera Editrice

Connor, C. (2017). Pioneer priests and makeshift altars. Irondale, AL: EWTN Publishing Inc.

Cox, H. (1965). The Secular City. New York: Macmillan

Flannery, A. (1981 ed). Vatican Council II. Northport, New York: Costello Publishing Company

Gee, E. (1991). Gender differences in church attendance in Canada: The role of labor force participation. Review of Religious Research, 32(3), 267-273.

Gonzalez, S. (2020). The mystery of faith. U.S. Catholic, 85(5), 25-27

Haack, A. (2019). "100 years later: An analysis into factors that affected mortality during the 1918 Spanish flu pandemic." Honors Thesis. 49. https://red.library.usd.edu/honors-thesis/49

Hinshaw, D. (July 7, 2020). "Trump moves to pull U.S. out of World Health Organization in midst of Covid-19 pandemic." The Wall Street Journal. www.wsj.com

Imbelli, R. P. (September 9, 2007). "Sine dominico non possumus." Commonweal. www.commonwealmagazine.org

Inazu, J. (March 18, 2020). "Close the churches. State and local shutdown orders shouldn't exempt religious gatherings, and those communities should comply." The Atlantic www.theatlantic.com

Jelten, T. G. (April 1, 2020). "States consider whether religious services qualify as "essential"” NPR. www.npr.org

Jonson, K. (April 14, 2020). "DOJ sides with Mississippi church in COVID-19 challenge; church accuses police of discrimination." USA Today. www.usatoday.com

Kerr, D (June 27, 2011): Pope: "Without the eucharist, the church simply does not exist." National catholic Register. www.ncregister.com

Krause, N., and Wulff, K. (2005). Friendship ties in the church and depressive symptoms: Exploring variations by age. Review of Religious Research, 46(4), 325-340.

Lazerwitz, B. (1961). Some factors associated with variations in church attendance. Social Forces, 39(4), 301309, https://doi.org/10.2307/2573426

Le, L. T. (2006). The Eucharist and the Church in the Thought of Henri de Lubac. Irish Theological Quarterly, $71(3-4), 338-347$.

Lee, E. (June 28, 2020). "Harvard researchers reveal unequal impact of COVID-19 on Black and Latinx Americans." The Harvard Crimson. www.thecrimson.com

Lima M. L., and Sobral, J. M. (2020). Threat and oblivion: Interpreting the silence over the Spanish flu (1918-19). In: Jodelet D., Vala J., Drozda-Senkowska E. (eds.) Societies under threat. Frontiers in Sociology and Social Research, 3. Springer, Cham. https://doi.org/10.1007/978-3-030-39315-1_15

Maslow, A. (1943). A theory of human motivation. Psychological Review, 50, 370-396 
National Directory for Catechesis (2005). Washington DC: United States Conference of Catholic Bishops.

Nicas, J. (March 14, 2020). "He has 17,700 bottles of hand sanitizer and nowhere to sell them." The New York Times. www.nytimes.com

Okeahialam, U. P. (2015). From the fence to the field. Growing in the knowledge and living the faith as a catholic. Mustang, Oklahoma: Tate Publishing

Olson, P. J., and Beckworth, D. (2011). Religious change and stability: Seasonality in church attendance from the 1940 s to the 2000s. Journal for the Scientific Study of Religion 50(2), 388 - 396.

Osborne, K. B. (2007). Community, eucharist and spirituality. Ligouri, Missouri: Ligouri Press

Phillips, H. (2008). Why did it happen? Religious explanations of the Spanish flu epidemic in South Africa. Historically Speaking 9(7), 34-36.

Philips, H. 1987). Why did it happen? Religious and lay explanations of the Spanish 'flu epidemic of 1918 in South Africa. Kronos, 12, 72-92

Podles, L. (1999). The church impotent. The feminization of christianity. Dallas, TX: Spence Publishing Company

Reilly, C. (2020). "The 1919 flu pandemic and the Diocese of Melbourne" melbourneanglican.org.au

Sanger, D. E. (May 3, 2020). "Pompeo ties coronavirus to China lab, despite spy agencies uncertainty." The New York Times. www.nytimes.com

Shimek, J. P. (October 16, 2014). "Diocesan synods offer opportunities for catholic church renewal." National Catholic Register. www.ncregister.com

Siddiqi, M., Graves-Fitzsimmons, G., and Gonzalez, E. (March 27, 2020). "Religious exemptions during the coronavirus pandemic will only worsen the crisis." Center for American Progress. scholarworks.wmich.edu

Stetler, C. M. (2017). The 1918 Spanish influenza. Three months of horror in Philadelphia. Pennsylvania History: A Journal of Mid-Atlantic Studies, 84 (4). 463-487

Teihard de Chardin, P. (1965). Hymn of the universe. New York: Harper \& Row

Thompson, M. A. and Bolten, S. (2018). They buckled on the armor of God: Kentucky catholic sister "Nurses" in the 1918 flu pandemic. American Catholic Studies 129(4), 91-105.

Winter, L. (March 13, 2020). "Chinese officials blame US army for coronavirus." The Scientist. www.thescientist.com

Worgul, G. S. (1980). From magic to metaphor. A validation of the Christian sacraments. New York: Paulist Press

World Bank. (June 8, 2020). "The global economic outlook during the COVID-19 pandemic: A changing world." www.worldbank.org

Zimmermann, C. (April 15, 2020). "Shutdown of religious services in pandemic prompts varied responses." Catholic News Services. www.ncronline.org 